\title{
Influence of Integrated Nutrient Management on Oil Content, Nutrient Uptake and Yields of Mustard Grown in Additive and Replacement Series in Chickpea + Mustard Intercropping System
}

\author{
Dimple Kaparwan $^{1 *}$, N.S. Rana ${ }^{1}$, Vivek ${ }^{1}$ and B.P. Dhyani ${ }^{2}$ \\ ${ }^{1}$ Department of Agronomy, ${ }^{2}$ Department of Soil Science, Sardar Vallabh bhai Patel University \\ of Agriculture \& Technology, Meerut 250110, U.P., India \\ *Corresponding author
}

\section{Keywords \\ Chickpea+Mustard intercropping, Integrated nutrient management; Rhizobium, Azotobacter, PSB, FYM, Replacement series, Additive series}

Article Info

Accepted: 18 May 2020 Available Online: 10 June 2020

\section{A B S T R A C T}

The biggest challenge for the developing nations like India is to meet the requirements of food supply for continuous growing population and ensuring nutritional security. Despite the achievement of green and other like revolutions, India still faces problem of protein and energy malnutrition which is a serious issue to be dealt with. Compared to our traditional rice and wheat farming system, the status of expanding oilseeds and pulses offers a limited scope due to less productivity, low returns, higher insect \& pest infestation and other associated risks involved. Since, the availability of land is a major constraint in Indian agriculture, therefore possibility of intensification of crops gives a viable option to improve the land use efficiency and increase profitability. Mustard and black gram are the major rabi season crops having seasonal and rhizospheric compatibility and therefore chickpea +mustard is a prominent intercropping system in irrigated areas of northern India. However, a little work has been done on chickpea+ mustard intercropping and information related to their comparative performance, competition relations and sustainability of the system coupled with beneficial effect of integrated use of various inorganic and organic nutrients is lacking, which might be helpful in enhancing the yield of the component crops. Keeping the foregoing facts in view, an experiment was conducted to find out the suitability of mustard as intercrop with chickpea, their appropriate row arrangement and nutrient doses for component crops. An investigation entitled "Population Compatibility and Nutrient Management Studies in Chickpea (Cicer arietinum L.) +Mustard (Brassica juncea L.) Intercropping System" was carried out at "Sardar Vallabhbhai Patel University of Agriculture and Technology", Meerut (U.P.) during rabi season of 2017-18. Recommended dose of fertilizer for chickpea and mustard were $100 \mathrm{~kg}$ DAP $+20 \mathrm{~kg} \mathrm{~S} \mathrm{ha}{ }^{-1}$ $\& 120 \mathrm{~kg} \mathrm{~N}+40 \mathrm{~kg} \mathrm{P}_{2} \mathrm{O}_{5}+20 \mathrm{~kg} \mathrm{~S}$. Chickpea seeds were inoculated with Rhizobium and mustard seeds with Azotobacter while PSB was soil applied. Chickpea and mustard seeds were sown manually in line at a depth of 8 and $4 \mathrm{~cm}$ with a spacing of $30 \mathrm{X} 15 \mathrm{~cm}$ in chickpea while in case of mustard the spacing varied according to intercropping situations. The results revealed that among different intercropping treatments, highest grain yield, straw yield \& total nutrient uptake in mustard was recorded in chickpea+ mustard 3:1 additive series while oil content was maximum recorded in chickpea +mustard 4:1 replacement series. Further, among different nutrient management options, application of $150 \%$ RDF in mustard (as per plant population) inoculated with Azotobacter $+100 \%$ RDF in chickpea inoculated with Rhizobium along with soil application of PSB resulted in highest yields, harvest index, oil content and total nutrient uptake while lowest was recorded with the application of recommended dose of fertilizer to the component crops. 


\section{Introduction}

In developing nations, food and nutritional security have remained a major challenge to cope up with low per capita availability of various food items in the country. Though, globally India ranks first in both area and production of pulses \& oilseeds, yet there is an alarming gap between demand and supply of these commodities. In our country, total area and production under pulses is 28 million hectares and 20.5 million tonnes with annual demand of 24 million tonnes (Directorate of Economics \& Statistics, 2018). On oilseeds front, India has made significant stride with an area and production of major oilseeds (9) being respectively 26.11 million hectare and 24.88 million tonnes whereas the total edible oil production in the country stood at 6.17 million tonnes in 2017-18. However, to meet the gap in annual growth rate of production $(2 \%)$ and demand $(6 \%)$ for vegetable oils and fats has been a major concern. The three important oilseed crops which share 80 percent of the total area and 87 per cent of production are groundnut, soybean and rapeseed-mustard.

Chickpea and mustard are major pulse and oilseed crops of India having seasonal and micro-climatic compatibility that constitutes a prominent cropping system under resource constraint conditions. Bishnoi et al., (1992) observed beneficial effects of chickpea intercropping on mustard which were related to improved microclimatic conditions. Many researchers have indicated that intercropping of both these crops in appropriate row ratios might increase the total crop production per unit area due to better utilization of resources and less competing ability attributed to their differential shoot, root and canopy characteristics. Kaushik and Chaubey (2001) studied the productivity of mustard intercropping with chickpea, peas and lentil against pure stand in North Indian condition and reported that mustard seed yield was higher in sole cropping than the intercropping system. He further told that among the intercropping systems, mustard + chickpea obtained the highest mustard seed yield (15.54 $\mathrm{q} \mathrm{ha}^{-1}$ ) and gave higher mustard seed equivalent, land equivalent ratio, income equivalent ratio and net returns as compared to mustard + pea and mustard + lentil intercropping systems. Similar to these findings, Singh and Pal (1993) reported that despite of $25 \%$ mustard population in intercropping with chickpea, mustard produced about $50 \%$ seed yield as compared to sole crop. Similarly, Kumar and Prasad (1998) reported from Kanpur that about 13\% more seed yield of mustard was obtained due to beneficial effect of chickpea in intercropping system. Also, the key to boost up crop production is the balanced nutrition of soil. However, due to continuous use of huge quantities of inorganic fertilizers by farmers has deteriorated the fertility status of the soil to a level that even application of fertilizers at higher rates is not able to sustain the soil productivity. Therefore, in order to sustain soil health and productivity there should be combined use of organic and inorganic nutrient sources.

The few studies conducted on integrated use of fertilizers with farm yard manure and biofertilizers in chickpea and mustard intercropping systems revealed that combined use of FYM with fertilizers not only led to enhancement in the productivity of these crops but sustainability of productivity over the years (Arya et al., 2010). Bio-fertilizers are low cost, non bulky and environmental friendly agricultural inputs which are used as a supplementary and complementary component for chemical fertilizers, which could improve plant nutrition (Sahai, 2004). Dual inoculation with phosphate solubilizing bacteria (PSB) and Rhizobium strains along with organic manure increases the macro and 
micro nutrient content in soil under moisture stress conditions. However, it is not possible to supply all the nutrient requirements of crops completely through organic manures (Singh and Rathi, 2003). Hence, use of organic nutrient sources along with chemical fertilizers is recommended in order to increase crop production without deterioration of soil under intensive modern agriculture. Therefore, the present study was carried out to investigate the effect of intercropping system and nutrient management options on yields, nutrient uptake and oil content of mustard under chickpea +mustard intercropping system in north-western part of India.

\section{Materials and Methods}

\section{Experimental details}

A research trial in the field was conducted during rabi season 2017-18 at Sardar Vallabhbhai Patel University of Agriculture and Technology, Meerut (U.P.), located at a latitude of $29^{\circ} 40^{\prime}$ North and longitude of $77^{0}$ 42' East with an elevation of 237 metres above mean sea level. The mean annual rainfall in the region is about $650 \mathrm{~mm}$ and the area lies in the heart of Western Uttar Pradesh. The research experiment field was well drained, sandy loam in texture with a $\mathrm{pH}$ of 7.9 and was low in available nitrogen and medium in available phosphorus \& potassium. Twenty treatment combinations of 04 intercropping systems viz., Chickpea + mustard in $3: 1$ and $4: 1$ both in additive and replacement series and 05 nutrient management options viz., recommended dose (RD) to chickpea and mustard both $\left(\mathrm{N}_{1}\right), \mathrm{N}_{1}+$ biofertilizers, $\mathrm{N}_{2}+\mathrm{FYM}\left(\mathrm{N}_{3}\right), \mathrm{N}_{1}$ but mustard with $150 \% \mathrm{RD}\left(\mathrm{N}_{4}\right)$ and $\mathrm{N}_{4}$ with biofertilizers along with sole cropping of component crops were tested in randomized block design with 3 replications. Recommended dose of fertilizer for chickpea and mustard were 100 $\mathrm{kg}$ DAP +20kg S ha ${ }^{-1} \& 120 \mathrm{~kg} \mathrm{~N}+40 \mathrm{~kg}$ $\mathrm{P}_{2} \mathrm{O}_{5}+20 \mathrm{~kg}$ S. Chickpea seeds were inoculated with Rhizobium and mustard seeds with Azotobacter while PSB was soil applied. Nutrient application to mustard was made as per population against sole stand. Chickpea and mustard seeds were sown manually in line at a depth of 8 and $4 \mathrm{~cm}$ with a spacing of $30 \times 15 \mathrm{~cm}$ in chickpea while in case of mustard the spacing varied according to intercropping situations.

\section{Data collection}

Various parameters like nutrient uptake, oil content and yields were recorded post harvest of mustard. Grain and straw yield was estimated by the produce obtained from net plot area of each treatment.

\section{Plant sampling and analysis}

After the harvesting and threshing of mustard, seed and straw samples were drawn from each treatment and thereafter plant samples were dried at a temperature of $70{ }^{\circ} \mathrm{C}$ in a hot air oven. Nutrient content in grain and straw samples of mustard plants were estimated separately for each treatment. All the samples were ground upto 20 mesh sieve using Wiley Mill grinder and digested in a diacid mixture of $\mathrm{HNO}_{3}: \mathrm{HClO}_{4}$ in 3:1 ratio followed by estimation of total nitrogen, phosphorus and potassium content by micro Kjeldahl, vanadomolybdo phosphoric acid yellow color method and using flame photometer respectively (Page, 1982). The nitrogen, phosphorus and potassium uptake was calculated by multiplying the yield $\left(\mathrm{kg} \mathrm{ha}^{-1}\right)$ with the respective nutrient content (\%) and nutrient uptake in grain and straw was summed up to calculate the total uptake for each nutrient. Also, oil content in mustard seed was estimated by Pulsed Nuclear Magnetic Resonance (N.M.R.) Technique (Tiwari and Burk, 1980). 


\section{Statistical analysis}

The data on nutrient uptake, oil content and yields were recorded as per the standard procedure. The significance of treatment effects were computed with the help of ' $F$ ' test and to judge the significance of difference between means of two treatments, critical difference (CD, at 5 per cent probability) was worked out as described by Gomez and Gomez (1984).

\section{Results and Discussion}

\section{Nutrient uptake in mustard}

\section{Nitrogen uptake}

Nitrogen uptake in mustard varied significantly under different intercropping systems and nutrient management options. Maximum uptake of nitrogen in grain and straw of mustard was recorded in sole cropping against intercropping treatments. Among intercropping situations, highest nitrogen uptake was found in chickpea + mustard 3:1 additive series while lowest was recorded in chickpea + mustard 4:1 replacement series. With regard to nutrient management options, higher value of nitrogen uptake in mustard was recorded with application of $150 \%$ RDF in mustard treated with Azotobacter $+100 \%$ RDF in chickpea treated with Rhizobium + PSB as soil applied, which was at par with nutrient management option of similar fertilizer dose without biofertilizers and RDF in chickpea + mustard along with bio-fertilizer inoculation + FYM, while superior over RDF to component crops. Similar results were given by Reddy et al., (1988), who revealed that there was significant increase in nitrogen and $\mathrm{P}_{2} \mathrm{O}_{5}$ uptake with increasing levels of $\mathrm{P}_{2} \mathrm{O}_{5}$ from 0 , 15 and $30 \mathrm{~kg} \mathrm{P}_{2} \mathrm{O}_{5} \mathrm{ha}^{-1}$ in mustard. Similarly, in a field experiment carried out by Singh et al., (1997a), they observed that application of
$\mathrm{P}_{2} \mathrm{O}_{5}$ upto $60 \mathrm{~kg} \mathrm{ha}^{-1}$ increased the uptake of nitrogen and phosphorus by mustard in pure as well as intercropping systems. Also, in a field trial carried out by Thakur and Chand (1998), they reported that nitrogen and sulphur uptake in gobhi sarson was higher with $60 \mathrm{~kg} \mathrm{P}_{2} \mathrm{O}_{5} \mathrm{ha}^{-1}$ over lower doses, though increase was significant only during one out of the two year trials.

\section{Phosphorous uptake}

Intercropping systems and nutrient management options significantly affected the phosphorous uptake in grain and straw of mustard. Phosphorous uptake in mustard was found to be lower in intercropping treatments as compared to sole mustard. Among the intercropping situations, highest phosphorous uptake in mustard was observed in chickpea + mustard 3:1 additive series while lowest in chickpea +mustard 4:1 replacement series. Among different nutrient management options, application of RDF to chickpea and mustard resulted in lowest phosphorous uptake in grain and straw while highest phosphorous uptake was recorded with nutrient dose of $150 \% \mathrm{RDF}$ in mustard inoculated with Azotobacter $+100 \%$ RDF in chickpea inoculated with Rhizobium + PSB as soil applied. Similar results were given by Prasad et al., (1991), who stated that application of $100 \mathrm{~kg} \mathrm{P}_{2} \mathrm{O}_{5}$ and 10 tonnes poultry manure $\mathrm{ha}^{-1}$ resulted in highest phosphorous, sulphur and iron uptake in mustard.

\section{Potassium uptake}

Potassium uptake in grain and straw of mustard varied significantly among different intercropping situations and nutrient management options. Maximum value of potassium uptake in grain and straw of mustard was recorded when grown in sole cropping against all intercropping treatments. 
Among different intercropping situations, highest uptake of potassium was recorded in chickpea + mustard 3:1 additive series while least uptake of potassium was under chickpea + mustard 4:1 replacement series. Among various nutrient management options, integrated nutrient application of $100 \%$ RDF in chickpea inoculated with Rhizobium +150 $\%$ RDF in mustard with Azotobacter + PSB as soil applied, recorded highest potassium uptake against all nutrient management strategies. These findings are in close agreement with the results of Prasad et al., (2006) and Ahlawat et al., (2005).

\section{Oil content (\%)}

Intercropping systems and nutrient management options had non- significant affect on oil content of mustard. Mustard grown in chickpea +mustard 4:1 replacement series recorded highest oil content in comparison to all intercropping treatments and sole cropping. Among different nutrient management options, application of nutrient dose of $100 \%$ RDF in chickpea inoculated with Rhizobium $+150 \%$ RDF in mustard with Azotobacter + PSB, recorded highest oil content against all nutrient management options while lowest oil content in mustard was recorded with RDF applied in component crops. Similar results were given by Trivedi et al., (1995), who reported that there was significant increase in oil content in mustard with increasing doses of $\mathrm{P}_{2} \mathrm{O}_{5}$ upto highest dose of $40 \mathrm{~kg} \mathrm{P}_{2} \mathrm{O}_{5} \mathrm{ha}^{-1}$. Also, Arthamwar et al., (1996) studied the effect of $\mathrm{P}_{2} \mathrm{O}_{5}$ with three doses $\left(0,40\right.$ and $\left.80 \mathrm{~kg} \mathrm{P}_{2} \mathrm{O}_{5}\right)$ on mustard and found that there was significant increase in oil content of mustard with increasing dose of $\mathrm{P}_{2} \mathrm{O}_{5}$ upto $80 \mathrm{~kg} \mathrm{P}_{2} \mathrm{O}_{5} \mathrm{ha}^{-1}$. Further, Yadav et al., (2010), reported that application of $125 \%$ recommended dose of NPK fertilizers induced significantly higher growth and yield characters, water use efficiency, protein, oil content and oil yield over other treatments and yielded $29.03 \%, 19.59 \%$ and $8.30 \%$ more seed yield over 50, 75 and $100 \%$ recommended dose of fertilizers, respectively.

\section{Yields}

\section{Grain yield (q ha $\left.{ }^{-1}\right)$}

Intercropping treatments and nutrient management options had significant effect on grain yield of mustard. Among different intercropping systems, highest yield of mustard was obtained in chickpea + mustard 3:1 additive series which was at par with respective 4:1 and significantly superior over chickpea + mustard 4:1 and 3:1 replacement series. Similar results were noted by Kumar and Singh (1987) in their research and revealed that intercropped mustard had higher number of branches and siliquae plant ${ }^{-1}$ in chickpea + mustard intercropping with $3: 1$ or $4: 1$ row ratio as compared to sole stand. With regard to nutrient management options, application of $150 \%$ RDF in mustard treated with Azotobacter $+100 \%$ RDF in chickpea treated with Rhizobium + PSB recorded higher grain yield over rest of the nutrient doses. Lowest grain yield was obtained with nutrient mgt option of RDF to component crops. Similar results were given by Mudholkar and Ahlawat (1979) who reported that application of $\mathrm{P}_{2} \mathrm{O}_{5}$ enhanced seed yield of mustard significantly over control. Also, in a study conducted to study the effect of integrated nutrient management on Indian mustard at Pantnagar by Tripathi et al., (2010)., they revealed that application of $2 \mathrm{t}$ $\mathrm{FYM}+40 \mathrm{~kg} \mathrm{~S}$ along with RDF or $75 \% \mathrm{RDF}$ resulted in significant increase in mustard yield i.e. 18.2 and 3\% over RDF. However, net returns indicated that INM treatment i.e. $\mathrm{RDF}+\mathrm{FYM}+\mathrm{S}+\mathrm{Zn}+\mathrm{B}+$ Azatobacter with mean returns of Rs. 19505 is promising to rest of the treatments. 


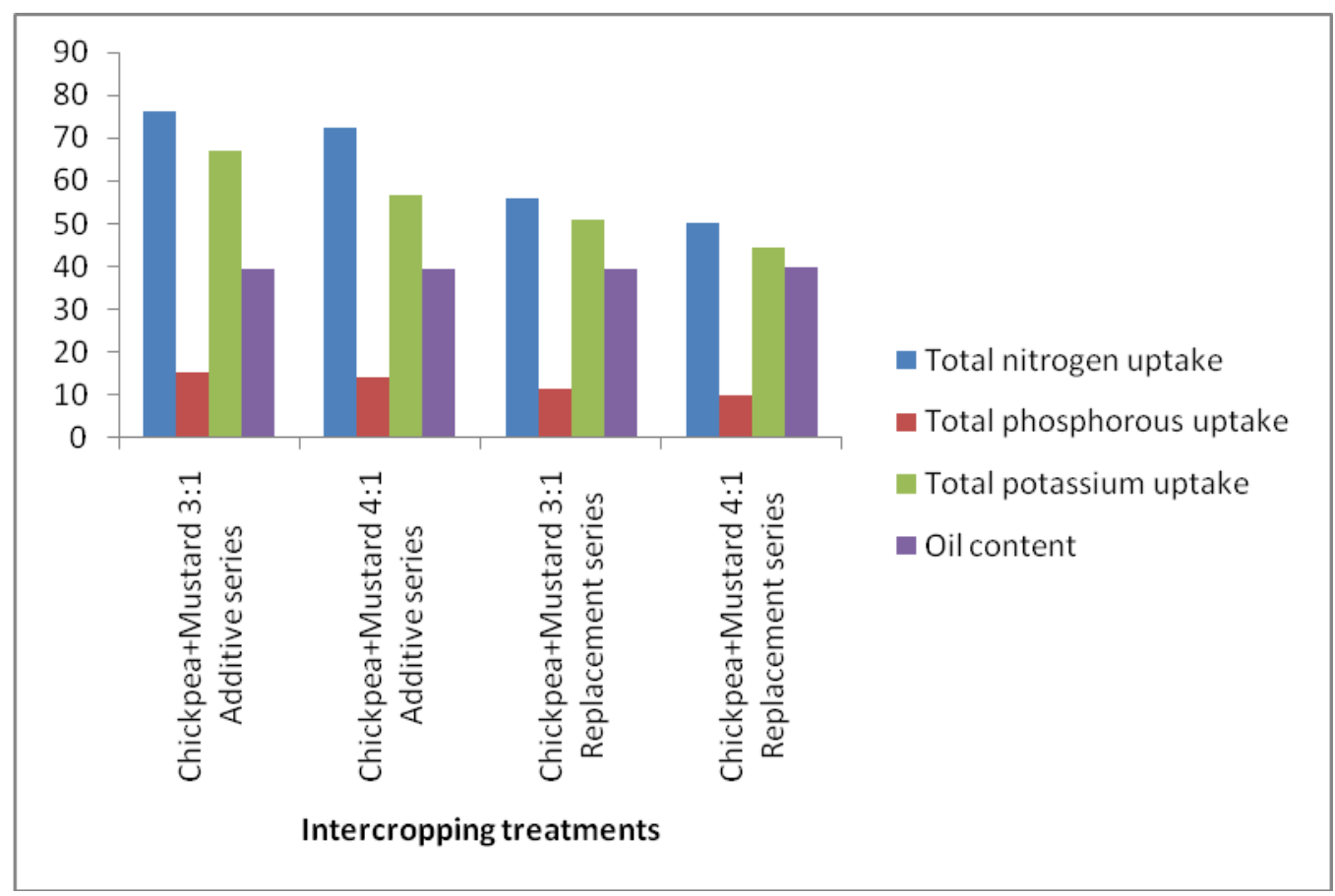

Figure.1 Effect of intercropping system on oil content, total nitrogen, phosphorous \& potassium uptake of mustard

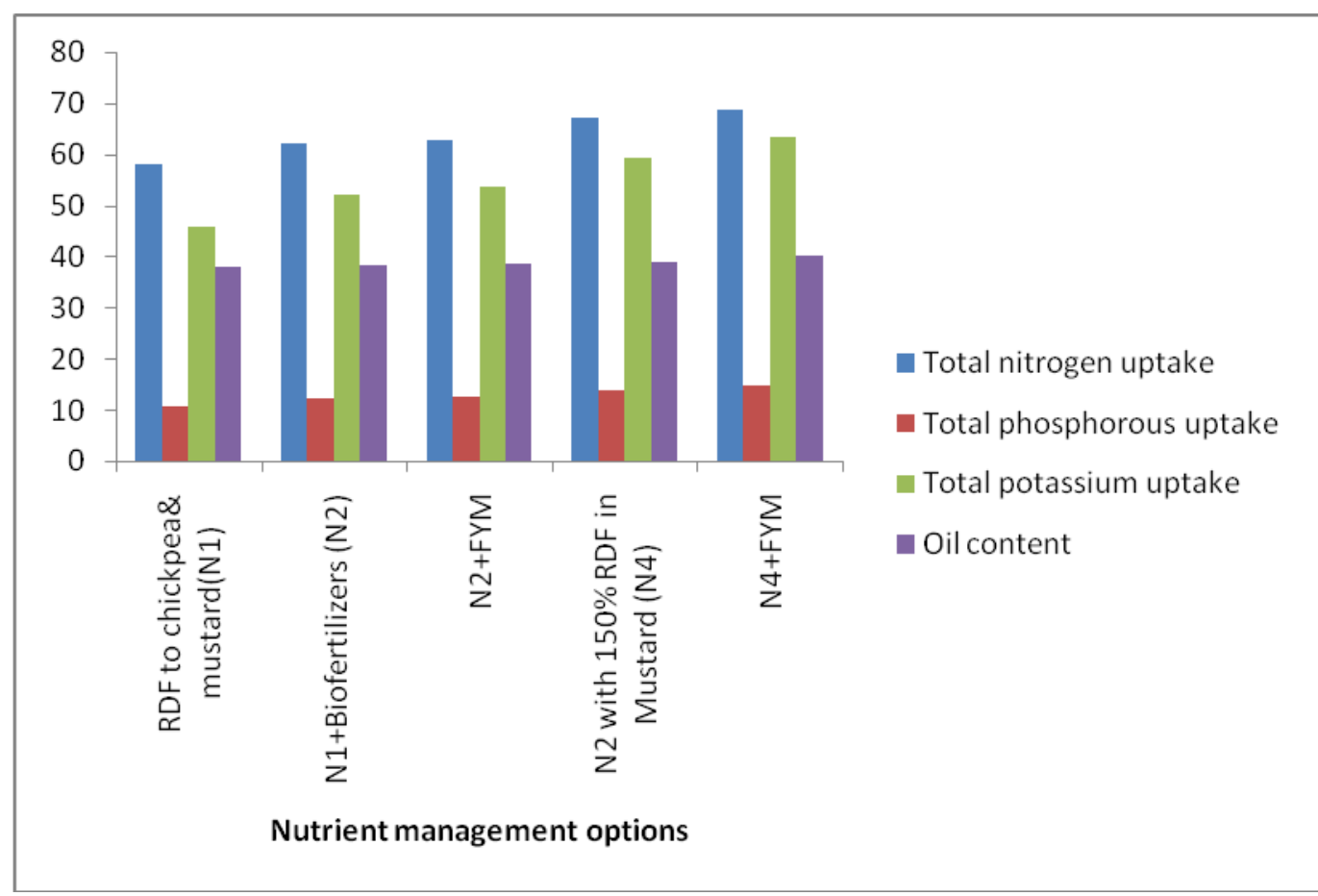

Figure.2 Effect of nutrient management options on oil content, total nitrogen, phosphorous $\&$ potassium uptake of mustard 


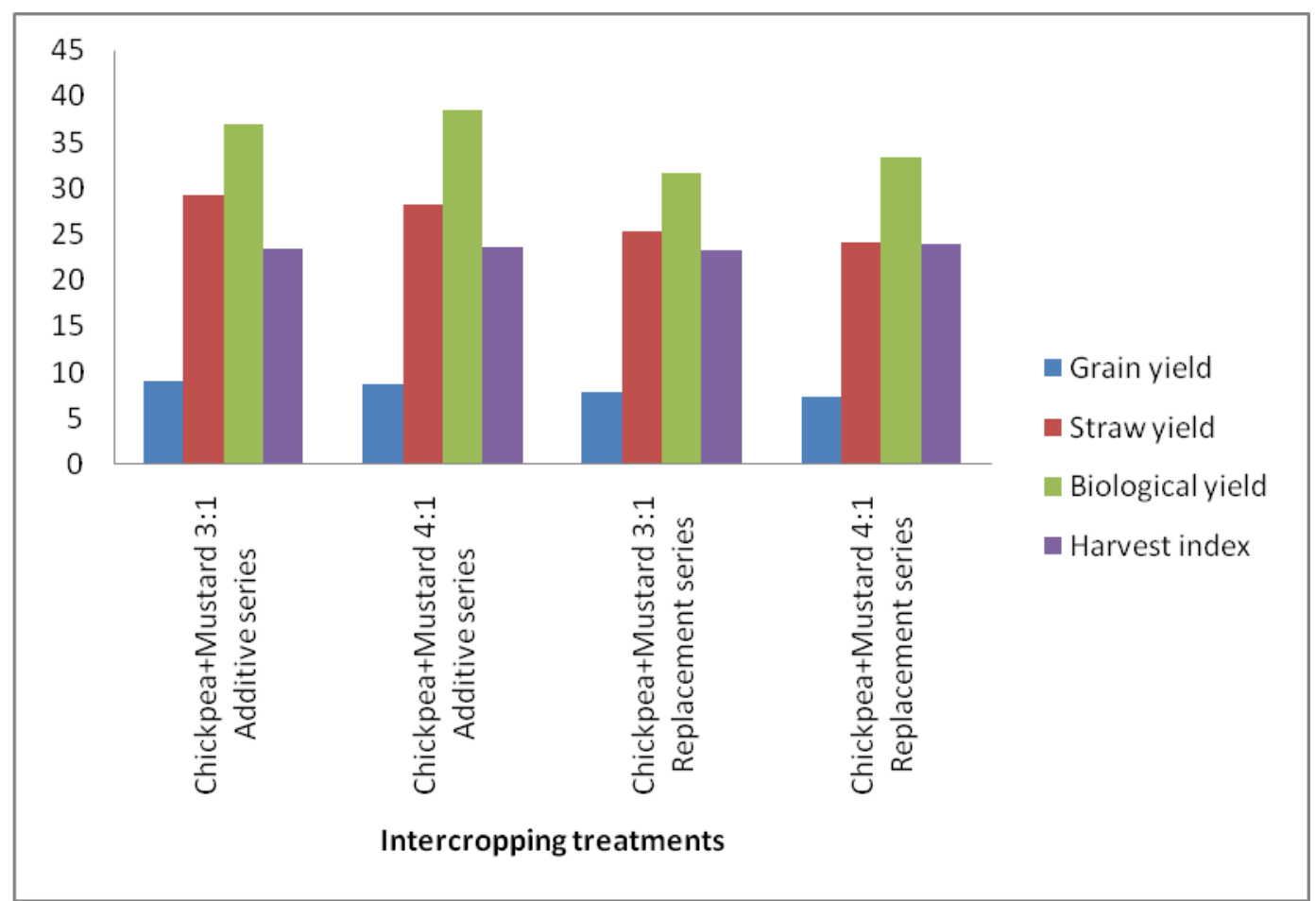

Figure.3 Effect of intercropping system on yields and harvest index of mustard

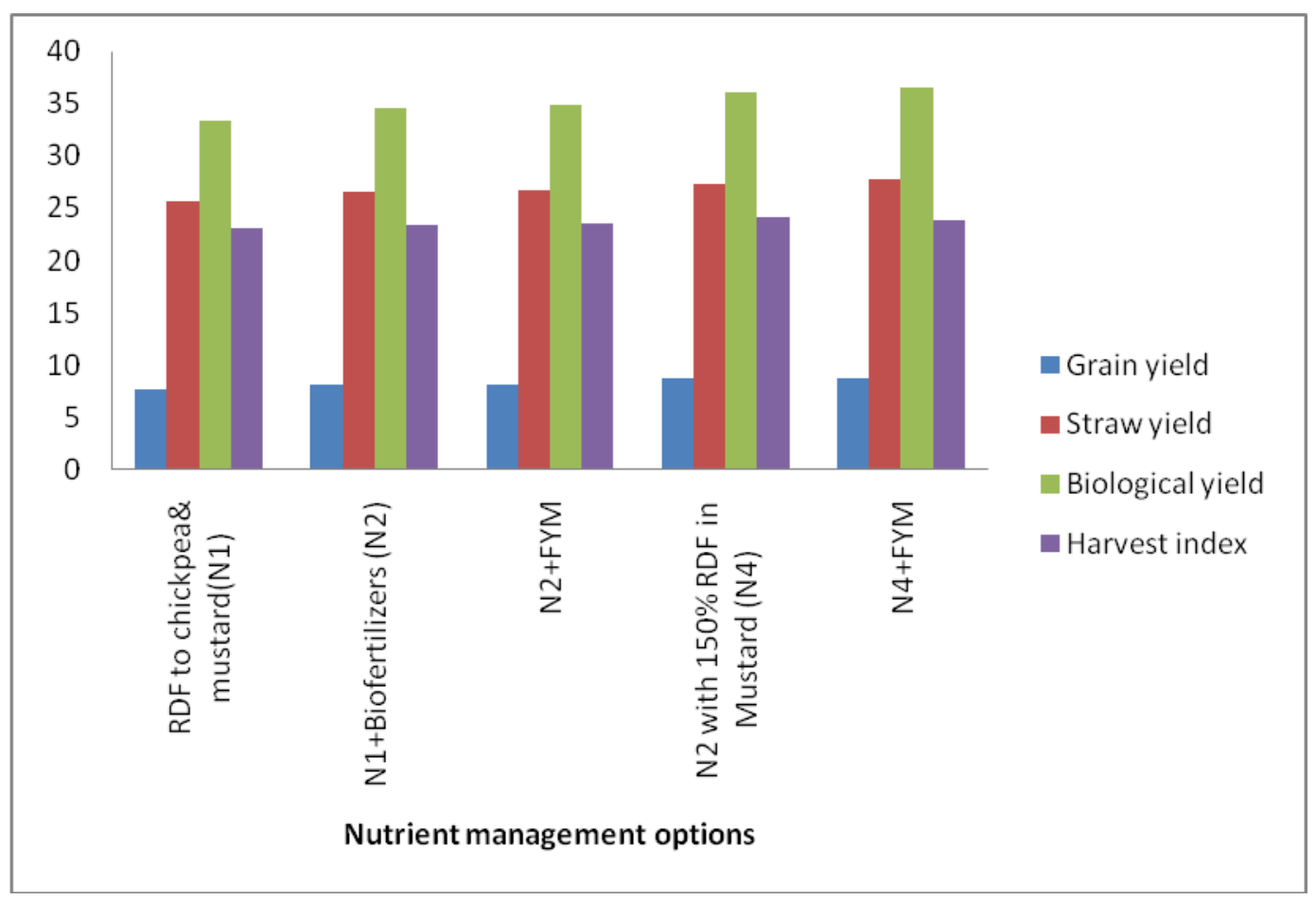

Figure.4 Effect of nutrient management options on yields and harvest index of mustard. 
Table.1 Effect of intercropping system and nutrient management options on yields, harvest index and oil content in mustard

\begin{tabular}{|c|c|c|c|c|c|c|}
\hline \multirow{2}{*}{\multicolumn{2}{|c|}{ Treatment }} & \multicolumn{4}{|c|}{ Yield $\left(\mathbf{q}\right.$ ha $\left.^{-1}\right)$} & \multirow{2}{*}{$\begin{array}{c}\text { Oil conten } \\
(\%)\end{array}$} \\
\hline & & Grain & Straw & Biological & Harvest index & \\
\hline \multicolumn{2}{|l|}{ Sole Mustard } & 16.9 & 44.9 & 61.8 & 27.4 & 38.1 \\
\hline \multicolumn{7}{|c|}{ Cropping system } \\
\hline \multicolumn{2}{|c|}{ Chickpea + mustard (3:1 A) } & 9.1 & 29.3 & 37.0 & 23.5 & 39.5 \\
\hline \multicolumn{2}{|c|}{ Chickpea + mustard (4:1 A) } & 8.7 & 28.3 & 38.5 & 23.6 & 39.5 \\
\hline \multicolumn{2}{|c|}{ Chickpea + mustard (3:1 R) } & 7.9 & 25.3 & 31.6 & 23.3 & 39.3 \\
\hline \multicolumn{2}{|c|}{ Chickpea + mustard (4:1 R) } & 7.4 & 24.2 & 33.3 & 23.9 & 39.8 \\
\hline \multicolumn{2}{|l|}{$\mathrm{SEm} \pm$} & 0.13 & 0.43 & 0.56 & 0.002 & 0.57 \\
\hline \multicolumn{2}{|l|}{$\mathrm{CD}(\mathrm{P}=\mathbf{0 . 0 5})$} & 0.38 & 1.22 & 1.60 & 0.005 & NS \\
\hline \multicolumn{7}{|c|}{ Nutrient Management Options } \\
\hline \multicolumn{7}{|c|}{\begin{tabular}{l|l} 
Chickpea & Mustard
\end{tabular}} \\
\hline RDF & RDF & 7.7 & 25.6 & 33.4 & 23.1 & 38.0 \\
\hline \multirow[t]{2}{*}{ RDF + Rhizo. } & RDF + Azato. & 8.1 & 26.5 & 34.6 & 23.4 & 38.2 \\
\hline & \multicolumn{6}{|c|}{ PSB } \\
\hline RDF + Rhizo. & RDF + Azato. & 8.2 & 26.7 & 34.9 & 23.5 & 38.6 \\
\hline \multicolumn{7}{|c|}{ PSB +FYM } \\
\hline RDF & $150 \% \mathrm{RDF}$ & 8.7 & 27.3 & 36.0 & 24.1 & 38.9 \\
\hline RDF + Rhizo. & $150 \%$ RDF + Azato. & 8.7 & 27.8 & 36.6 & 23.8 & 40.2 \\
\hline \multicolumn{7}{|c|}{ PSB } \\
\hline \multicolumn{2}{|l|}{ SEm \pm} & 0.15 & 0.48 & 0.62 & 0.002 & 0.64 \\
\hline \multicolumn{2}{|l|}{$\mathrm{CD}(\mathrm{P}=\mathbf{0 . 0 5})$} & 0.42 & 1.36 & 1.78 & 0.005 & NS \\
\hline
\end{tabular}


Table.2 Effect of intercropping system and nutrient management options on total nutrient uptake in mustard

\begin{tabular}{|c|c|c|c|c|c|c|c|c|c|c|}
\hline \multirow{2}{*}{\multicolumn{2}{|c|}{ Treatment }} & \multicolumn{3}{|c|}{ Nitrogen uptake $\left(\mathrm{kg} \mathrm{ha}^{-1}\right)$} & \multicolumn{3}{|c|}{ Phosphorus uptake $\left(\mathrm{kg} \mathrm{ha}^{-1}\right)$} & \multicolumn{3}{|c|}{ Potassium uptake $\left(\mathrm{kg} \mathrm{ha}^{-1}\right)$} \\
\hline & & Grain & Straw & Total & Grain & Straw & Total & Grain & Straw & Total \\
\hline Sole Mustard & & 55.12 & 67.38 & 122.50 & 9.67 & 14.82 & 24.49 & 25.44 & 76.36 & 101.80 \\
\hline \multicolumn{11}{|c|}{ Cropping system } \\
\hline \multicolumn{2}{|c|}{ Chickpea + mustard (3:1 A) } & 30.46 & 45.99 & 76.46 & 5.32 & 10.26 & 15.59 & 14.74 & 52.44 & 67.18 \\
\hline \multicolumn{2}{|c|}{ Chickpea + mustard (4:1 A) } & 28.65 & 43.55 & 72.20 & 4.98 & 9.09 & 14.07 & 13.48 & 43.34 & 56.82 \\
\hline \multicolumn{2}{|c|}{ Chickpea + mustard (3:1 R) } & 22.40 & 33.75 & 56.15 & 4.08 & 7.48 & 11.56 & 10.70 & 40.25 & 50.95 \\
\hline \multicolumn{2}{|c|}{ Chickpea + mustard (4:1 R) } & 19.83 & 30.40 & 50.23 & 3.48 & 6.58 & 10.06 & 9.08 & 35.56 & 44.65 \\
\hline \multicolumn{2}{|c|}{ SEm \pm} & 0.81 & 1.23 & 2.04 & 0.14 & 0.23 & 0.37 & 0.31 & 1.12 & 1.44 \\
\hline \multicolumn{2}{|l|}{$\mathrm{CD}(\mathrm{P}=\mathbf{0 . 0 5})$} & 2.33 & 3.52 & 5.85 & 0.41 & 0.65 & 1.05 & 0.90 & 3.21 & 4.11 \\
\hline \multicolumn{11}{|c|}{ Nutrient Management Options } \\
\hline \multicolumn{11}{|l|}{ Chickpea } \\
\hline RDF & RDF & 22.72 & 35.33 & 58.05 & 3.75 & 6.93 & 10.68 & 10.33 & 35.56 & 45.89 \\
\hline \multirow[t]{2}{*}{ RDF + Rhizo. } & RDF + Azato. & 24.57 & 37.46 & 62.03 & 4.29 & 8.03 & 12.32 & 11.51 & 40.53 & 52.05 \\
\hline & \multicolumn{10}{|l|}{ PSB } \\
\hline RDF + Rhizo. & RDF + Azato. & 25.06 & 37.94 & 62.99 & 4.37 & 8.14 & 12.52 & 11.82 & 41.94 & 53.76 \\
\hline \multicolumn{11}{|c|}{ PSB +FYM } \\
\hline RDF & $150 \% \mathrm{RDF}$ & 26.98 & 40.03 & 67.02 & 4.88 & 9.04 & 13.92 & 13.01 & 46.42 & 59.44 \\
\hline RDF + Rhizo. & $150 \%$ RDF + Azato. & 27.35 & 41.36 & 68.71 & 5.04 & 9.63 & 14.67 & 13.33 & 50.03 & 63.37 \\
\hline \multicolumn{11}{|c|}{ PSB } \\
\hline \multirow{2}{*}{\multicolumn{2}{|c|}{$\begin{array}{l}\text { SEm } \pm \\
\text { CD }(P=0.05)\end{array}$}} & 0.91 & 1.37 & 2.28 & 0.16 & 0.25 & 0.41 & 0.35 & 1.25 & 1.61 \\
\hline & & 2.61 & 3.94 & 6.55 & 0.46 & 0.72 & 1.17 & 1.00 & 3.59 & 4.60 \\
\hline
\end{tabular}




\section{Straw yield $\left(\mathbf{q} \mathbf{h a}^{-1}\right)$}

Straw yield of mustard was significantly affected under different intercropping treatments and nutrient management options. Sole crop of mustard recorded higher straw yield against all intercropping treatments followed by chickpea + mustard 3:1 additive series which was at par with respective $4: 1$ additive and significantly superior over chickpea + mustard 3:1 and 4:1 replacement series. Among various nutrient mgt treatments, nutrients dose of $150 \% \mathrm{RDF}$ in mustard treated with Azotobacter $+100 \%$ RDF in chickpea treated with rhizobium + PSB, produced highest straw yield which was at par with same dose to component crops without biofertilizers, and significantly superior over rest of the nutrient management options. The higher grain and straw yield was mainly due to higher dry matter accumulation and also more translocation of photosynthates towards sink. Similar findings were also reported by Chand et al., (2004) and Arya et al., (2007).

\section{Biological yield $\left(\mathrm{q} \mathrm{ha}^{-1}\right)$}

Significant effect of intercropping treatments and nutrient management options was noted in biological yield of mustard. Maximum amount of biological yield was produced in sole mustard followed by chickpea +mustard 3:1 additive series which was at par with respective 4:1 additive and significantly superior over chickpea + mustard 3:1 and 4:1 replacement series. Further, component crops supplied with nutrient management option of $150 \%$ RDF in mustard treated with Azotobacter $+100 \%$ RDF in chickpea treated with Rhizobium + PSB as soil applied, recorded highest biological yield in comparison to other nutrient management options. Similar finding were given by Abraham and Lal (2002).

\section{Harvest index}

Intercropping treatments and nutrient management options had significant impact on harvest index of mustard. In comparison to intercropping treatments, sole crop of mustard recorded significantly higher value of harvest index. Among intercropping systems, greater value of harvest index was obtained in chickpea + mustard 4:1 replacement series followed by chickpea + mustard $4: 1$ and $3: 1$ additive series. Similar findings were also reported by Upasani (1994). With regard to nutrient management options, highest value of harvest index was obtained when mustard was fertilized with $150 \%$ RDF along with Azotobacter inoculation $+100 \%$ RDF in chickpea inoculated with Rhizobium + PSB, against rest of the nutrient management $s$. These findings are in close agreement with the results of Prasad et al., (2006).

Based on above findings it can be concluded that intensification of mustard proves beneficial in 3:1 \& 4:1 additive series along with fertilizer application of $100 \mathrm{~kg}$ DAP $+20 \mathrm{~kg} \mathrm{~S}$ ha $^{-1}$ to chickpea + Rhizobium inoculation and $30 \mathrm{~kg} \mathrm{~N}, 10 \mathrm{~kg} \mathrm{P}_{2} \mathrm{O}_{5}$ and $5 \mathrm{~kg}$ $\mathrm{S} \mathrm{ha}^{-1}$ to mustard +Azotobacter inoculation and soil application of PSB under chickpea + mustard Intercropping System. Though recommendations of practical utility have been given on the basis of present investigation, still more field research is needed to find compatibility of crops and row ratios coupled with nutrient management strategies to be adopted in intercropping systems.

\section{References}

Abraham, T. and Lal, R.B. (2002). Strategies for INM technology in sustainable edapho-cultivar management for a legume based (Soyabean-mustardfodder cowpea) cropping system for the Inceptisoil in the NEPZ. Crop research, 
Hisar, 26 (1): 33-41.

Abraham, T., Thenua, O.V.S. and Sharma, U.C. (2011) Evaluation performance of chickpea and mustard intercropping system viz.-a-viz. their sole crops as influenced by irrigation regimes and fertility gradients. Indian Journal of Agricultural Sciences 81(8): 772-775.

Ahlawat, I.P.S., Gangaiah, B and Singh, O. (2005) Production potential of chickpea (Cicer arietinum) based intercropping systems under irrigated condition. Indian Journal of Agronomy 50 (1): 27 30.

Arthamwar, D.N.; Shelke, V.B. and Ekshinge, B.S. (1996). Effect of nitrogen and phosphorus on yield attributes, seed and oil yield of Indian mustard (B. juncea). Indian journal of Agronomy., 41(2): 282-285.

Arya, R. L., Varshney, J.G. and Kumar, L. (2007) Effect on integrated nutrient application in chickpea + mustard intercropping systems in the semi-arid tropics of North India. Soil Science and Plant Analysis 38 (1/2): 229-240.

Arya, R.L. and Jain, V. (2003) Identification of different ideotypes of desi and kabuli chickpea varieties in chickpea+mustard intercropping system. Paper presented in National Symposium on resource management for eco-friendly crop production. CSAUA\&T, Kanpur. P.8.

Bishnoi, O.P.; Tanya, K.D.; Rao, V.V.M. and Singh, R. (1992). Microclimatic influence of intercropping of chickpea with mustard on the yield and yield attributes. Haryana Journal of Agronomy, 8 (1): 7-12.

Chand, S., Tripathi, H.N., and Tripathi, A.K. (2004) Phosphorus requirement of gram (Cicer arietinum)+Indian mustard (Brassica juncea) intercropping system.under irrigated conditions. Indian Journal of Agricultural Sciences 74 (4): 207-209.

Gomez, K. A. and. Gomez, A. A. 1984. Statistical procedure for Agricultural Research An international Rice
Research Institute Book. John Willey and sons, 2nd edition. 329.

Kumar, A. and Prasad, K. (1998). Studies on screening of suitable chickpea varieties for chickpea + mustard intercropping. M.sc. (Ag.) Thesis submitted to Deptt. of Agronomy C.S.A.U.T. Kanpur.

Kumar, A. and Singh, B.P. (2006) Effect of row ratio and phosphorus level on performance of chickpea (Cicer arietinum) + Indian mustard (Brassica juncea) intercropping. Indian Journal of Agronomy, 51(2): 100-102.

Mudholkar, N.J. and Ahlawat, I.P.S. (1979). Response of Bengal gram to nitrogen, phosphorus and molibdenum. Indian Journal of Agronomy, 24 (1): 61-65.

Page A L. 1982. Methods of Soil Analysis: Part 2. Chemical and Microbiological Properties. American Society of Agronomy, Soil Science Society of America, Madison, WI, USA.

Pandhi, A.K. and Panigarahi, R.K. (2006) Effect of inter cropping and crop geometry on productivity, economics, energetic and soil fertility status of Maize based intercropping system. Indian Journal of Agronomy 51 (3): 174-177.

Prasad, F.M., Chandra, A. and Verma, M.M. (1991). Growth, yield, dry matter and nutrient uptake by mustard in alluvial soil as influenced by phosphorus and organic matter. New Agriculturist. 2 (1): 31-34.

Prasad, K., Singh, R. K. and Pyare, R. (2006) Studies on intercropping of mustered varieties with chickpea. Indian Journal of Pulse Research 19(1): 73-75.

Rana, K.S., Pal, M., Kumar, P., Pal, M. and Kumar, P. (1996) Studies on fertilization under dry land conditions. Annals of Agricultural Research 17(3): 305-307.

Rana, K.S., Rana, D.S. and Gautam, R.C. (2005) Influence of phosphorus, sulphur and boron on growth, yield, nutrient uptake and economics of Indian mustard (Brassica juncea) under rain fed 
conditions. Indian Journal of Agronomy. 50(4): 314-316.

Reddy, B.N. and Singh, M.N. (1989). Integrated fertilizer and water management to boost mustard production. Indian farming. 39 (5): 5-6.

Sah, D., Bohra, J.S and Shukla, D.N. (2006). Effect of $\mathrm{N}, \mathrm{P}$ and $\mathrm{S}$ on growth attributes of and nutrient uptake by Indian mustard. Crop Research Hissar.31(1):52- 55

Singh, D. and Pal, M. (1993). Intercropping of mustard with chickpea under rainfed conditions. Crop Research, Hisar. 6 (1): 162-164.

Singh, F., Sinsinwar, B.S., Premi, O.P., Kumar, M., Singh, F., and Kumar, M. (2002) Effect of lowest Agricultural techniques on the sustained productivity of mustard (Brassica juncea).Annals of Agricultural Research 23(4):638- 641.

Singh, K.K. and Rathi, K.S. (2003) Dry matter production and productivity as influenced by staggered sowing of mustard intercropped at different row ratios with Chickpea. Journal of Agronomy and Crop Science, 189(3): 169- 175 .

Singh, M., Singh, H.B. and Giri , G. (1997a). Dry matter accumulation and NP-uptake by mustard and chickpea as influenced by intercropping and levels of nitrogen and phosphorus. Annals of Agricultural research. 18 (3): 135-142.

Thakur, K.S. and Chand, J. (1998). Response and economics in relation to nitrogen and phosphorus nutrition in gobhi sarson under rainfed conditions. Indian Journal of Agronomy, 43 (4): 733-737.

Tripathi, H.N., Chand, S. and Tripathi, A.K. (2005) Biological and economical feasibility of chickpea (Cicer arientinum) + Indian mustard (Brassica juncea) cropping systems under varying levels of phosphorus. Indian Journal of Agronomy, 50(1): 31-34.

Tripathi, M.K., Sumit, Chaturvedi.; D.K. Shukla, and B.S. Mahapatra (2010). Yield performance and quality in Indian mustard (Brassica juncea L.) as affected by integrated nutrient management. Indian Journal of Agronomy, 55(2): 138-142.

Trivedi, S.K., Singh, V. and Shinde, O.P. (1995). Effect of various levels of N, P and $\mathrm{S}$ on yield and quality of mustard (Brassica juncea Coss L.) in intercropping system. Crop research, Hisar, 10(3): 265-270.

Upasani, R.R. (1994) Intercropping in gram. Indian Journal of Agronomy 39(1): 111113.

\section{How to cite this article:}

Dimple Kaparwan, N.S. Rana, Vivek and Dhyani, B.P. 2020. Influence of Integrated Nutrient Management on Oil Content, Nutrient Uptake and Yields of Mustard Grown in Additive and Replacement Series in Chickpea + Mustard Intercropping System. Int.J.Curr.Microbiol.App.Sci. 9(06): 832-843. doi: https://doi.org/10.20546/ijcmas.2020.906.106 